\title{
Synthesis and Biological Evaluation of Novel 1,3-Benzoxathiol-2-one Sulfonamides against Toxic Activities of the Venom of Bothrops jararaca and Bothrops jararacussu Snakes
}

\author{
Eliza L. Chazin, ${ }^{a}$ Leonardo B. Martins, ${ }^{a}$ Marcus Vinícius N. de Souza, ${ }^{b}$ \\ Claudia Regina B. Gomes, ${ }^{b}$ Ana Cláudia R. da Silva, ${ }^{c}$ Marcelly C. Branco, ${ }^{c}$ \\ Eladio F. Sanchez, ${ }^{d}$ André L. Fuly*,c and Thatyana R. A. Vasconcelos ${ }^{\circledR *, a}$ \\ ${ }^{a}$ Departamento de Química Orgânica, Instituto de Química, Universidade Federal Fluminense, \\ 24020-141 Niterói-RJ, Brazil \\ ${ }^{b}$ Instituto de Tecnologia em Fármacos, Farmanguinhos, Fundação Oswaldo Cruz, \\ 21041-250 Rio de Janeiro-RJ, Brazil \\ 'Departamento de Biologia Celular e Molecular, Instituto de Biologia, \\ Universidade Federal Fluminense, 24020-140 Niterói-RJ, Brazil \\ ${ }^{d}$ Centro de Pesquisa e Desenvolvimento, Fundação Ezequiel Dias, \\ 30510-010 Belo Horizonte-MG, Brazil
}

\begin{abstract}
This work describes the synthesis of new 1,3-benzoxathiol-2-one sulfonamides and evaluation of their ability to inhibit some in vitro (coagulant, proteolytic and hemolytic) and in vivo (hemorrhagic, edematogenic and lethality) toxic activities of Bothrops jararaca and Bothrops jararacussu venoms. Compounds have been synthesized from the coupling of intermediate 5-amino-6-methoxybenzo $[d]$ [1,3] oxathiol-2-one 4 with benzenesulfonyl chlorides. Characterization of the products was achieved by nuclear magnetic resonance (NMR) and electrospray ionization mass spectra (ESI-MS) techniques. Biological assay results have shown that most of compounds inhibited the main toxic activities of the venom of the two snake species. Compound $\mathbf{5 b}(N-(6-$ methoxy-2-oxobenzo $[d]$ [1,3] oxathiol-5-yl)-4-nitrobenzenesulfonamide) was the most efficient in inhibiting hemolysis of B. jararaca, and coagulation and proteolysis induced by both venoms. For in vivo activities, all compounds inhibited the edema, from 35 to $72 \%$, and most of them exhibited antihemorrhagic and antilethality activities. Thus, the results pointed to the biological potential of these compounds, being promising molecules to treat envenomation by these snakes as well as to aid the current antivenom serum therapy.
\end{abstract}

Keywords: 1,3-benzoxathiol-2-ones, sulfonamides, snake venom, Bothrops jararaca, Bothrops jararacussu, antivenom

\section{Introduction}

Snake venoms are complex mixtures of proteins with or without enzymatic activity, including metalloproteinases, serine proteinases, phospholipases $\mathrm{A}_{2}$, and L-amino acid oxidase. According to World Health Organization (WHO), snakebite envenoming represents a public health problem worldwide and is considered a neglected disease. ${ }^{1,2}$

In Brazil, the venomous pit vipers Bothrops are responsible for the majority of snakebites $(90 \%)$, and $B$. jararaca and $B$. jararacussu are amongst the highest venomous species. B. jararaca is found in southern

*e-mail: andrefuly@id.uff.br; thatyanavasconcelos@id.uff.br Editors handled this article: Teodoro S. Kaufman and Brenno A. D. Neto (Associate) of Brazil, Paraguay, and northern of Argentina; while B. jararacussu is found in Brazil (from Bahia to Santa Catarina), Paraguay, southeastern Bolivia, and northeastern Argentina. Envenoming by these snakes shares some common features, as bleeding, renal or cardiac failure, hemorrhage, edema or massive tissue necrosis. ${ }^{3}$ In fact, $B$. jararaca or $B$. jararacussu bite induces severe symptoms, and usually leads victims to death or amputation of the affected limb. The treatment of snake bites is performed by injecting polyvalent or monovalent antivenom, that despite neutralizing systemic effects and preventing the death of victims, it does not block efficiently local effects, as tissue necrosis. ${ }^{4}$ Besides, as consequences, morbidities and amputation may occur as well as it may induce side effects into victims, as early anaphylactic reactions and 
fever. ${ }^{5,6}$ Thus, seeking for strategies to block toxic effects of snake venom is a considerable challenge, and natural products have been investigated, elsewhere. ${ }^{7}$ On the other hand, molecules derived from organic synthesis have not been widely investigated. In this context, heterocycles play an essential role in drug design, since they comprise a class of substances of great synthetic interest due to their occurrence in natural products and pharmacologically active compounds. ${ }^{8-12}$ In particular, 1,3-benzoxathiol-2one and its derivatives have been found to possess diverse biological activities, such as antibacterial, antifungal, antioxidant, anticancer, anti-inflammatory and carbonic anhydrase and monoamine oxidase (MAO) enzymes inhibitors. ${ }^{13-18}$ To the best of our knowledge, the antivenom effect of such class of molecules has not been studied. On the other hand, sulfonamide derivatives have already been reported for their ability to neutralize the hemolytic activity of the venom of Lachesis muta, ${ }^{19}$ as well as to inhibit some in vitro and in vivo toxic effects of the venoms of B. jararaca or $L$. muta $^{20}$ Besides, drugs derived from sulfa have been utilized in some pharmaceutical applications due to their antibacterial, antiviral, antimalarial, antifungal, anticancer, antidepressant and other properties..$^{21,22}$

In continuation of our efforts on the synthesis of new biologically active 1,3-benzoxathiol-2-one-based compounds, we herein report the synthesis of new 1,3-benzoxathiol-2-one sulfonamides and evaluation of their ability to inhibit some toxic in vitro and in vivo activities of $B$. jararaca and B. jararacussu venoms.

\section{Experimental}

\section{Chemistry}

Reactions were routinely monitored by thin-layer chromatography (TLC) on silica-gel precoated $\mathrm{F}_{254}$ Merck plates (Darmstadt, Germany) visualized under UV light $(254-366 \mathrm{~nm})$. Melting points were determined on a Fisatom 430 apparatus (São Paulo, Brazil) and are uncorrected. Catalytic hydrogenation reaction was performed on a Paar 4540 reactor (Moline, USA). Infrared (IR) spectra were recorded on a PerkinElmer 1420 spectrometer (Waltham, USA) using $\mathrm{KBr}$ pellets and frequencies are expressed in $\mathrm{cm}^{-1}$. Electrospray ionization mass spectra (ESI-MS) in the negative ion mode were recorded on a Waters ZQ-4000 single quadrupole mass spectrometer (Milford, USA). Nuclear magnetic resonance (NMR) spectra were recorded on a Varian Unity Plus 300 and 500 (Palo Alto, USA) spectrometers in dimethyl sulfoxide (DMSO- $d_{6}$ ), which was used as the deuterated solvent (Cambridge Isotope Laboratories Inc., Tewksburry, USA). Chemical shifts $(\delta)$ are reported in parts per million (ppm) relative to tetramethylsilane (TMS), which was used as an internal standard. All reagents and solvents were used as obtained from commercial suppliers without further purification. In addition, pyridine, ethyl acetate, hydrochloric acid, diethyl ether and magnesium sulfate were purchased from Vetec Química Fina LTDA (Duque de Caxias, Brazil). Finally, 6-hydroxybenzo[ $d][1,3]$ oxathiol-2-one, 4-substituted benzenesulfonyl chlorides and 4-(dimethylamino)pyridine (DMAP) were obtained from Sigma-Aldrich (São Paulo, Brazil).

\section{Procedures for preparing 1,3-benzoxathiol-2-one derivatives}

\section{2, 3 and 4}

Protocols for the preparation, physical and spectroscopic data of compounds $\mathbf{2}, \mathbf{3}$ and $\mathbf{4}$ have already been reported in our previous papers. ${ }^{13-15}$

General procedure for the synthesis of sulfonamides (5a-5h)

In a round-bottom flask, pyridine $(10 \mathrm{~mL}), 5$-amino6-methoxybenzo[ $d][1,3]$ oxathiol-2-one (4) $(1 \mathrm{mmol})$, the appropriate 4-substituted benzenesulfonyl chloride $(1.5 \mathrm{mmol})$ and DMAP ( $1 \mathrm{mmol})$ were added. The system was heated at reflux for $8 \mathrm{~h}$. Then, the solution was neutralized with concentrated $\mathrm{HCl}$. The reaction mixture was extracted with ethyl acetate $(4 \times 20 \mathrm{~mL})$, the combined organic layers were dried over $\mathrm{MgSO}_{4}$ and evaporated under reduced pressure. The oil obtained was triturated with diethyl ether to afford a solid product. After completing the crystallization, the solid was filtered and was washed with hot water followed by diethyl ether.

$N$-(6-Methoxy-2-oxobenzo[d][1,3]oxathiol-5-yl)-4-methylbenzenesulfonamide (5a)

Yield: $48 \%$; mp 171-173 ${ }^{\circ} \mathrm{C}$; IR (KBr) v / $\mathrm{cm}^{-1} 3258$ $(\mathrm{N}-\mathrm{H}), 1768(\mathrm{C}=\mathrm{O}), 1336(\mathrm{~S}=\mathrm{O}), 1161(\mathrm{~S}=\mathrm{O}) ;{ }^{1} \mathrm{H}$ NMR $\left(500.00 \mathrm{MHz}, \mathrm{DMSO}-d_{6}\right) \delta 9.52(\mathrm{~s}, 1 \mathrm{H}, \mathrm{N} \underline{\mathrm{H}}), 7.64(\mathrm{~s}, 1 \mathrm{H}$, H7), 7.57 (d, 2H, J 8.0 Hz, H2'/H6'), 7.32 (d, 2H, J $8.0 \mathrm{~Hz}$, H3'/H5'), 7.16 (s, 1H, H4), 3.46 (s, 3H, OC$\left.{ }_{3}\right), 2.35$ (s, 3H, $\left.\mathrm{C}_{3}\right) ;{ }^{13} \mathrm{C}$ NMR $\left(125.0 \mathrm{MHz}\right.$, DMSO- $\left.d_{6}\right) \delta 169.7(\mathrm{C}=\mathrm{O})$, 153.0 (C6), 146.1 (C7a), 142.8 (C4'), 137.4 (C1'), 129.1 (C3'/C5'), 126.7 (C2'/C6'), 123.1 (C5), 120.4 (C7), 112.5 (C3a), $97.2(\mathrm{C} 4), 56.1\left(\mathrm{OCH}_{3}\right), 20.9\left(\mathrm{CH}_{3}\right)$; ESI-MS $\mathrm{m} / z$, $[\mathrm{M}-\mathrm{H}]^{-}: 350.1\left([\mathrm{M}-\mathrm{H}]^{-} 100 \%\right)$.

$N$-(6-Methoxy-2-oxobenzo[d][1,3]oxathiol-5-yl)-4-nitrobenzenesulfonamide (5b)

Yield: 40\%; mp 215-217 ${ }^{\circ} \mathrm{C}$; IR (KBr) v / $\mathrm{cm}^{-1} 3257$ $(\mathrm{N}-\mathrm{H}), 1737(\mathrm{C}=\mathrm{O}), 1532(\mathrm{~N}-\mathrm{O}), 1348(\mathrm{~S}=\mathrm{O}), 1291(\mathrm{~N}-\mathrm{O})$, $1169(\mathrm{~S}=\mathrm{O}) ;{ }^{1} \mathrm{H}$ NMR $\left(500.00 \mathrm{MHz}, \mathrm{DMSO}-d_{6}\right) \delta 8.36$ (d, 
2H, J $8.9 \mathrm{~Hz}, \mathrm{H} 3$ '/H5'), 7.92 (d, 2H, J $8.9 \mathrm{~Hz}, \mathrm{H} 2^{\prime} / \mathrm{H} 6$ '), 7.65 (s, 1H, H7), 7.17 (s, $1 \mathrm{H}, \mathrm{H} 4), 3.41\left(\mathrm{~s}, 3 \mathrm{H}, \mathrm{OC}_{3}\right)$; ${ }^{13} \mathrm{C}$ NMR (75.0 MHz, DMSO- $\left.d_{6}\right) \delta 169.7(\mathrm{C}=\mathrm{O}), 153.8$ (C6), 149.6 (C7a or C1' or C4'), 146.9 (C7a or C1' or C4'), 146.0 (C7a or $\mathrm{C}^{\prime}$ ' or $\mathrm{C}^{\prime}$ '), 128.2 (C2'/C6'), 124.0 (C3'/ C5'), 122.3 (C7), 121.9 (C5), 112.7 (C3a), 97.3 (C4), 56.0 $\left(\mathrm{OCH}_{3}\right)$; ESI-MS $m / z,[\mathrm{M}-\mathrm{H}]^{-}: 381.1\left([\mathrm{M}-\mathrm{H}]^{-}\right.$100\%).

4-Fluoro- $N$-(6-methoxy-2-oxobenzo[d][1,3]oxathiol-5-yl) benzenesulfonamide (5c)

Yield: 25\%; mp 123-125 ${ }^{\circ} \mathrm{C}$; IR (KBr) $v / \mathrm{cm}^{-1} 3247$ $(\mathrm{N}-\mathrm{H}), 1760(\mathrm{C}=\mathrm{O}), 1340(\mathrm{~S}=\mathrm{O}), 1168(\mathrm{~S}=\mathrm{O}), 1157$ (C-F); ${ }^{1} \mathrm{H}$ NMR $\left(500.00 \mathrm{MHz}, \mathrm{DMSO}-d_{6}\right) \delta 7.73(\mathrm{dd}, 1 \mathrm{H}$, $J$ 9.0, $5.2 \mathrm{~Hz}, \mathrm{H} 2^{\prime} / \mathrm{H}^{\prime}$ ), 7.64 (s, 1H, H7), 7.36 (d, 2H, $J 8.9 \mathrm{~Hz}, \mathrm{H} 3{ }^{\prime} / \mathrm{H} 5$ '), 7.16 (s, 1H, H4), 3.47 (s, $\left.3 \mathrm{H}, \mathrm{OC}_{3}\right)$; ${ }^{13} \mathrm{C}$ NMR (75.0 MHz, DMSO- $\left.d_{6}\right) \delta 170.2(\mathrm{C}=\mathrm{O}), 164.7$ (d, ${ }^{\mathrm{C}-\mathrm{F}} J 251.1 \mathrm{~Hz}, \mathrm{C}^{\prime}$ '), 153.9 (C6), 147.0 (C7a), 137.2 (d, ${ }^{\mathrm{C}-\mathrm{F} J} 3.3 \mathrm{~Hz}, \mathrm{C}^{\prime}$ '), 130.2 (d, $\left.{ }^{\mathrm{C}-\mathrm{F} J} 9.6 \mathrm{~Hz}, \mathrm{C}^{\prime} / \mathrm{C} 6^{\prime}\right), 123.1$ (C5), 122.0 (C7), 116.4 (d, ${ }^{\mathrm{C}-\mathrm{F} J} 22.7 \mathrm{~Hz}, \mathrm{C}^{\prime} / \mathrm{C}^{\prime}$ '), 113.0 (C3a), 97.7 (C4), $56.6\left(\mathrm{OCH}_{3}\right)$; ESI-MS $m / z,[\mathrm{M}-\mathrm{H}]^{-}$: $354.1\left([\mathrm{M}-\mathrm{H}]^{-} 100 \%\right)$.

4-Bromo- $N$-(6-methoxy-2-oxobenzo[d][1,3]oxathiol-5-yl) benzenesulfonamide $\mathbf{( 5 d )}$

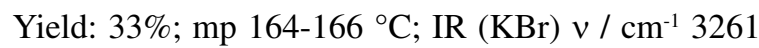
$(\mathrm{N}-\mathrm{H}), 1768(\mathrm{C}=\mathrm{O}), 1339(\mathrm{~S}=\mathrm{O}), 1161(\mathrm{~S}=\mathrm{O}) ;{ }^{1} \mathrm{H}$ NMR $\left(500.00 \mathrm{MHz}, \mathrm{DMSO}-d_{6}\right) \delta 9.78(\mathrm{~s}, 1 \mathrm{H}, \mathrm{N} \underline{\mathrm{H}}), 7.75(\mathrm{~d}, 2 \mathrm{H}$, $J$ 8.6 Hz, H2'/H6'), 7.65 (s, 1H, H7), 7.59 (d, 2H, J 8.6 Hz, $\mathrm{H} 3$ '/H5'), 7.18 (s, 1H, H4), 3.45 (s, 3H, $\left.\mathrm{OCH}_{3}\right) ;{ }^{13} \mathrm{C} \mathrm{NMR}$ $\left(125.0 \mathrm{MHz}, \mathrm{DMSO}-d_{6}\right) \delta 170.2(\mathrm{C}=\mathrm{O}), 153.9(\mathrm{C} 6), 147.1$ (C7a), 140.1 (C1'), 132.3 (C2'/C6'), 129.1 (C3'/C5'), 126.9 (C4'), 122.9 (C5), 122.0 (C7), 113.1 (C3a), 97.7 (C4), 56.6 $\left(\mathrm{OCH}_{3}\right)$; ESI-MS: $m / z[\mathrm{M}-\mathrm{H}]^{-}: 415.9\left([\mathrm{M}-\mathrm{H}]^{-} 100 \%\right)$.

4-Chloro- $N$-(6-methoxy-2-oxobenzo[d][1,3]oxathiol-5-yl) benzenesulfonamide $(\mathbf{5 e})$

Yield: $40 \%$; mp 98-100 ${ }^{\circ} \mathrm{C}$; IR (KBr) v / $\mathrm{cm}^{-1} 3244$ $(\mathrm{N}-\mathrm{H}), 1761(\mathrm{C}=\mathrm{O}), 1340(\mathrm{~S}=\mathrm{O}), 1165(\mathrm{~S}=\mathrm{O}) ;{ }^{1} \mathrm{H}$ NMR $\left(500.00 \mathrm{MHz}, \mathrm{DMSO}-d_{6}\right) \delta 7.67(\mathrm{~d}, 2 \mathrm{H}, J 8.6 \mathrm{~Hz}$, H2'/H6'), 7.64 (s, 1H, H7), 7.60 (d, 2H, J $8.6 \mathrm{~Hz}$, H3'/H5'), 7.17 (s, 1H, H4), 3.46 (s, 3H, OC$\left.\underline{H}_{3}\right) ;{ }^{13} \mathrm{C} \mathrm{NMR}$ $\left(75.0 \mathrm{MHz}, \mathrm{DMSO}-d_{6}\right) \delta 170.2(\mathrm{C}=\mathrm{O}), 153.9(\mathrm{C} 6), 147.1$ (C7a), 139.7 (C1' or C4'), 138.0 (C1' or C4'), 129.4 (C2'/ C6'), 129.1 (C3'/C5'), 123.0 (C5), 121.9 (C7), 113.1 (C3a), $97.8(\mathrm{C} 4), 56.6\left(\mathrm{OCH}_{3}\right)$; ESI-MS $m / z,[\mathrm{M}-\mathrm{H}]^{-}: 370.0$ $\left([\mathrm{M}-\mathrm{H}]^{-} 100 \%\right)$.

$N$-(6-Methoxy-2-oxobenzo[ $[d][1,3]$ oxathiol-5-yl) benzenesulfonamide (5f)

Yield: $46 \%$; mp 184-186 ${ }^{\circ} \mathrm{C}$; IR (KBr) $v / \mathrm{cm}^{-1} 3247$ $(\mathrm{N}-\mathrm{H}), 1762(\mathrm{C}=\mathrm{O}), 1344(\mathrm{~S}=\mathrm{O}), 1161(\mathrm{~S}=\mathrm{O}) ;{ }^{1} \mathrm{H}$ NMR $\left(500.00 \mathrm{MHz}, \mathrm{DMSO}-d_{6}\right) \delta 9.54(\mathrm{~s}, 1 \mathrm{H}, \mathrm{N} \underline{\mathrm{H}}), 7.69(\mathrm{~d}, 2 \mathrm{H}$, $J 7.4$ Hz, H2'/H6'), 7.64 (s, 1H, H7), 7.60 (tt, 1H, J 7.4, $\left.1.2 \mathrm{~Hz}, \mathrm{H} 4^{\prime}\right), 7.52$ (t, 2H, J 7.4 Hz, H3'/H5'), 7.14 (s, 1H, $\mathrm{H} 4), 3.44\left(\mathrm{~s}, 3 \mathrm{H}, \mathrm{OC}_{3}\right) ;{ }^{13} \mathrm{C}$ NMR $\left(75.0 \mathrm{MHz}\right.$, DMSO- $d_{6}$ ) $\delta 169.7(\mathrm{C}=\mathrm{O}), 153.2(\mathrm{C} 6), 146.3(\mathrm{C} 7 \mathrm{a}), 140.3\left(\mathrm{C} 1^{\prime}\right), 132.5$ (C4'), 128.7 (C3'/C5'), 126.6 (C2'/C6'), 122.9 (C5), 121.0 (C7), 112.5 (C3a), 97.2 (C4), $56.1\left(\mathrm{OCH}_{3}\right)$; ESI-MS m/z, $[\mathrm{M}-\mathrm{H}]^{-}: 336.1\left([\mathrm{M}-\mathrm{H}]^{-}\right.$100\%).

4-Methoxy- $N$-(6-methoxy-2-oxobenzo[d][1,3]oxathiol-5-yl) benzenesulfonamide $\mathbf{( 5 g})$

Yield: $41 \%$; mp 171-173 ${ }^{\circ} \mathrm{C}$; IR (KBr) v / $\mathrm{cm}^{-1} 3265$ $(\mathrm{N}-\mathrm{H}), 1765(\mathrm{C}=\mathrm{O}), 1334(\mathrm{~S}=\mathrm{O}), 1161(\mathrm{~S}=\mathrm{O}) ;{ }^{1} \mathrm{H} \mathrm{NMR}$ (500.00 MHz, DMSO- $\left.d_{6}\right) \delta 7.61-7.63$ (m, 3H, H7/H2'/H6'), 7.16 (s, 1H, H4), 7.03 (d, 2H, J 9.0 Hz, H3'/H5'), 3.81 (s, $\left.3 \mathrm{H}, \mathrm{OCH}_{3}\right), 3.50\left(\mathrm{~s}, 3 \mathrm{H}, \mathrm{OCH}_{3}\right) ;{ }^{13} \mathrm{C} \mathrm{NMR}(125.0 \mathrm{MHz}$, DMSO- $\left.d_{6}\right) \delta 169.8(\mathrm{C}=\mathrm{O}), 162.3$ (C6 or C4'), 153.0 (C6 or C4'), 146.1 (C7a), 131.9 (C1'), 128.9 (C2'/C6'), 123.3 (C5), 120.4 (C7), 113.9 (C3'/C5'), 112.5 (C3a), 97.2 (C4), $56.2\left(\mathrm{OCH}_{3}\right), 55.6\left(\mathrm{OCH}_{3}\right)$; ESI-MS $m / z,[\mathrm{M}-\mathrm{H}]^{-} 366.1$ $\left([\mathrm{M}-\mathrm{H}]^{-} 100 \%\right)$.

4-lodo- $N$-(6-methoxy-2-oxobenzo[d][1,3]oxathiol-5-yl) benzenesulfonamide $\mathbf{( 5 \mathbf { h } )}$

Yield: 51\%; mp 189-191 ${ }^{\circ} \mathrm{C}$; IR (KBr) $v / \mathrm{cm}^{-1} 3259$ $(\mathrm{N}-\mathrm{H}), 1768(\mathrm{C}=\mathrm{O}), 1338(\mathrm{~S}=\mathrm{O}), 1162(\mathrm{~S}=\mathrm{O}) ;{ }^{1} \mathrm{H}$ NMR $\left(500.00 \mathrm{MHz}, \mathrm{DMSO}-d_{6}\right) \delta 9.68(\mathrm{~s}, 1 \mathrm{H}, \mathrm{N} \underline{\mathrm{H}}), 7.92(\mathrm{~d}, 2 \mathrm{H}$, $J 8.5$ Hz, H3'/H5'), 7.62 (s, 1H, H7), 7.43 (d, 2H, J $8.5 \mathrm{~Hz}$, $\mathrm{H} 2^{\prime} / \mathrm{H}^{\prime}$ ) $), 7.17$ (s, 1H, H4), 3.47 (s, 3H, $\left.\mathrm{OCH}_{3}\right) ;{ }^{13} \mathrm{C} \mathrm{NMR}$ $\left(75.0 \mathrm{MHz}, \mathrm{DMSO}-d_{6}\right) \delta 169.7(\mathrm{C}=\mathrm{O}), 153.3(\mathrm{C} 6), 146.5$ (C7a), 140.0 (C1'), 137.6 (C2'/C6'), 128.3 (C3'/C5'), 122.2 (C5), 121.4 (C7), 112.6 (C3a), 100.4 (C4'), 97.2 (C4), 56.1 $\left(\mathrm{OCH}_{3}\right)$; ESI-MS $m / z,[\mathrm{M}-\mathrm{H}]^{-}: 461.9\left([\mathrm{M}-\mathrm{H}]^{-}\right.$100\%).

\section{Materials}

\section{Venoms, animals, and reagents}

Bothrops jararaca and B. jararacussu venoms were kindly supplied by Fundação Ezequiel Dias (FUNED), Belo Horizonte, Minas Gerais State, Brazil, and stored at $-20{ }^{\circ} \mathrm{C}$ until use. The collection of snake venom was conducted under the authorization of the Brazilian System for Management Genetic of Heritage and Associated Traditional Knowledge (SisGen) (process number A39CD4E). Balb/c mice (18-20 g) were obtained from the Laboratory Animal Care of the Federal Fluminense University (UFF) and were housed under constant temperature $\left(24 \pm 1{ }^{\circ} \mathrm{C}\right)$ and light conditions. Experiments were approved by the UFF Institutional Committee for Ethics in Animal Experimentation (protocol number 508), that are in accordance with the guidelines of the Brazilian 
Committee for Animal Experimentation (COBEA). All solvents or reagents were of the best grade available.

\section{Biological assays}

\section{Coagulant activity of venoms}

Different concentrations of $B$. jararaca or $B$. jararacussu venom $\left(5-70 \mu \mathrm{g} \mathrm{mL}^{-1}\right)$ were added to plasma and coagulation time was monitored using a digital Amelung coagulometer (model KC4A, Labcon, Germany). The amount of venom $\left(\mu \mathrm{g} \mathrm{mL}^{-1}\right)$ able to clot plasma around $60 \mathrm{~s}$ was called minimum coagulation dose (MCD), and such venom concentration (B. jararaca, $35 \mu \mathrm{g} \mathrm{mL}^{-1}$ or B. jararacussu, $50 \mu \mathrm{g} \mathrm{mL}^{-1}$ ) was incubated for $30 \mathrm{~min}$ at $25^{\circ} \mathrm{C}$ with compounds, at 1:10 venom:compound ratio $(\mathrm{m} / \mathrm{m})$. After incubation, mixture was added to the medium reaction and coagulation was monitored, as described. Control experiments were performed by incubating compounds, dimethyl sulfoxide (DMSO) $(0.8 \%$, final concentration) or saline with plasma in the absence of venoms.

\section{Proteolytic activity of venoms}

Proteolytic activity of $B$. jararaca and $B$. jararacussu venom was determined ${ }^{23}$ using azocasein as a substrate $(0.2 \% \mathrm{~m} / \mathrm{v}$, in $20 \mathrm{mM}$ Tris- $\mathrm{HCl}, 8 \mathrm{mM} \mathrm{CaCl}, \mathrm{pH} 8.8)$, with modifications. Different concentrations of each venom (2-40 $\left.\mu \mathrm{g} \mathrm{mL}^{-1}\right)$ were incubated with azocasein, and the amount of each venom that achieved supramaximal activity was considered as $100 \%$ of proteolytic activity, and called effective concentration (EC). The effect of compounds was evaluated by incubating one EC of $B$. jararaca or B. jararacussu $\left(10 \mu \mathrm{g} \mathrm{mL}^{-1}\right)$ venom with compounds $\left(100 \mu \mathrm{g} \mathrm{mL} \mathrm{L}^{-1}\right)$ for $30 \mathrm{~min}$ at $25^{\circ} \mathrm{C}$. Then, proteolytic activity was determined, as described. Control experiments were performed by incubating compounds, DMSO $(0.9 \%$, final concentration) or saline, instead of venoms.

\section{Hemolytic activity of venoms}

Hemolytic activity of the venom of $B$. jararacussu was not performed, because of the low hemolytic activity of this venom. On the other hand, the degree of hemolysis caused by the venom of $B$. jararaca was determined by the indirect hemolytic test using human erythrocytes and hen's egg yolk emulsion, as substrate. ${ }^{24}$ After performing a concentration-response curve $\left(5-50 \mu \mathrm{g} \mathrm{mL}^{-1}\right)$, the amount of venom $\left(\mu \mathrm{g} \mathrm{mL}^{-1}\right)$ able to induce $100 \%$ of hemolysis was called minimum indirect hemolytic concentration (MIHC). Then, one MIHC of B. jararaca $\left(24 \mu \mathrm{g} \mathrm{mL}^{-1}\right)$ venom was incubated with compounds $\left(240 \mu \mathrm{g} \mathrm{mL}^{-1}\right)$ or solvents (DMSO or saline) for $30 \mathrm{~min}$ at $25^{\circ} \mathrm{C}$, followed by the hemolytic test. Control experiments were performed by incubating venom with solvents in the absence of compounds or by adding solely compounds or solvents to reaction medium.

\section{Hemorrhagic activity of venoms}

Hemorrhagic lesions produced by $B$. jararaca and $B$. jararacussu venoms were quantified by the procedure described by Kondo et al. ${ }^{25}$ with modifications. B. jararaca or $B$. jararacussu venom was injected intradermally (i.d.) into the abdominal skin of mice, and $2 \mathrm{~h}$ later, animals were euthanized by decapitation, abdominal skin removed, stretched, and inspected for visual changes in the internal aspect in order to localize hemorrhagic spots. One minimum hemorrhagic dose (MHD) was defined as the amount of venom ( $\mu$ g per mice) able to produce a hemorrhagic halo of 10 millimeters that was $12 \mu \mathrm{g}$ per mice. The effect of compounds on venom-induced hemorrhage was investigated by incubating compounds with two MHD of B. jararaca or B. jararacussu venom ( $24 \mu \mathrm{g}$ per mice) for $30 \mathrm{~min}$ at $25^{\circ} \mathrm{C}$. After incubation, mixture was injected i.d. into mice, and hemorrhagic activity was performed, as described. Negative controls were performed by injecting solely saline, DMSO or compounds, instead of venom. The volume of injection of samples was $100 \mu \mathrm{L}$.

\section{Edematogenic activity of venoms}

Edema-inducing activity of venom was determined in accordance to Yamakawa et al. ${ }^{26}$ with modifications. Groups of five mice received a subcutaneous (s.c.) subplantar single injection of B. jararaca or B. jararacussu venom into the right paw; while the left one received a single injection of saline or DMSO. Then, $1 \mathrm{~h}$ after injection, the paws were amputated, weighed and edema was evaluated and expressed as the percentage of increase in the weight of the right foot paw compared to the left one. The effect of compounds was evaluated by incubating each venom ( $7 \mu \mathrm{g}$ per mice) with compounds ( $20 \mu \mathrm{g}$ per mice) for $30 \mathrm{~min}$ at $25{ }^{\circ} \mathrm{C}$, and then, an aliquot of this mixture was injected s.c. into mice. Control experiments were performed by injecting compounds or solvents in the absence of venom. The volume of injection of samples was $50 \mu \mathrm{L}$.

\section{Lethality activity of venoms}

B. jararaca or B. jararacussu venom (50 $\mu \mathrm{g}$ per mice) was incubated with solvents for $30 \mathrm{~min}$ at $25^{\circ} \mathrm{C}$, and an aliquot was injected intraperitoneally (i.p.) into mice, and deaths were observed and registered. Antilethality effect was performed by incubating each venom with compounds (150 $\mu \mathrm{g}$ per mice) at the same conditions. After incubation, 
mixture was injected i.p. into mice, and time of death was observed, and compared to the group that received injection of venoms alone. Negative control group received injection solely of compounds or solvents, instead of venom. After the end of injections, number of deaths of mice was observed over a period of $24 \mathrm{~h}$. The volume of injection of samples was $100 \mu \mathrm{L}$.

\section{Statistical analysis}

Results are expressed as means \pm standard deviation (SD). The statistical significance of differences amongst experimental groups was evaluated using the Student's $t$-test. $p$ values $<0.05$ were considered significant.

\section{Results and Discussion}

\section{Synthesis}

The 1,3-benzoxathiol-2-one sulfonamides $\mathbf{5 a - 5 h}$ were synthesized as shown in Scheme 1. First, the nitro derivative 2 was prepared from selective nitration at 5 -position of the commercially available 6-hydroxybenzo[ $d][1,3]$ oxathiol-2-one 1, using $\mathrm{HNO}_{3} 65 \%$ in $\mathrm{CH}_{2} \mathrm{Cl}_{2}$ at room temperature for $2 \mathrm{~h}$, in $75 \%$ yield. Subsequently, methylation of phenolic hydroxyl group of 2 using methyl iodide and $\mathrm{K}_{2} \mathrm{CO}_{3}$ in $N, N$-dimethylformamide (DMF) at room temperature for $24 \mathrm{~h}$, leading to the methoxy derivative 3 in $74 \%$ yield. Key intermediate 5-amino6-methoxybenzo[ $d][1,3]$ oxathiol-2-one (4) was obtained in excellent yield $(93 \%)$ by catalytic hydrogenation of 3 with $10 \% \mathrm{Pd} / \mathrm{C}$ in ethanol under $20 \mathrm{bar}_{2}$ pressure at $50{ }^{\circ} \mathrm{C}$ for 6-8 h. Melting points and spectral data of the intermediates 2-4 were consistent with literature. ${ }^{13-15}$ The new 1,3-benzoxathiol-2-one sulfonamides 5a-5h were obtained from the coupling of $\mathbf{4}$ with 4 -substituted benzenesulfonyl chlorides in the presence of pyridine and DMAP in 1 equivalent amount for $8 \mathrm{~h}$ at reflux in $25-51 \%$ yields.
Sulfonylation reaction between the amine $\mathbf{4}$ and different 4-substituted benzenesulfonyl chlorides was attempted with other methodologies by varying solvent, base, catalyst and temperature, as shown in Table 1. The protocols presented in entries 1 to 9 were unsuccessful. It is noteworthy the comparison between entries 9 and 10 , which corroborates with a proposal that, in this reaction, the DMAP plays a dual role as a base and nucleophilic catalyst, and therefore can activate both reactants in this reaction (Figure 1). ${ }^{27}$

The structures of the newly synthesized compounds were characterized by spectral data $\left({ }^{1} \mathrm{H} \mathrm{NMR},{ }^{13} \mathrm{C} \mathrm{NMR}\right.$, IR and ESI-MS). 2D-NMR techniques (correlated spectroscopy (COSY), heteronuclear single quantum coherence spectroscopy (HSQC) and heteronuclear multiple bond correlation (HMBC)) helped us to assign the correct signals of the compounds. The results of the spectral analysis were in accordance with the proposed structures. As an example, the ${ }^{1} \mathrm{H}$ NMR spectrum of compound $\mathbf{5 a}$ exhibited a broad singlet at $9.82 \mathrm{ppm}$ for $\mathrm{N}-\underline{\mathrm{H}}$. Hydrogens $\mathrm{H} 7$ and $\mathrm{H} 4$ appeared as singlets at 7.64 and $7.16 \mathrm{ppm}$, respectively. Hydrogens $\mathrm{H} 2$ '/H6' and H3'/H5' are shown as duplets at $7.57 \mathrm{ppm}(J 8.0 \mathrm{~Hz})$ and $7.32 \mathrm{ppm}(J 8.0 \mathrm{~Hz})$, respectively. Two singlets were identified at 3.46 and 2.35 ppm for $\mathrm{O}-\mathrm{C}_{3}$ and $\mathrm{CH}_{3}$ groups, respectively. The ${ }^{13} \mathrm{C}$ NMR spectrum exhibited the $\mathrm{C}=\mathrm{O}$ signal at $169.7 \mathrm{ppm}$, $\mathrm{OCH}_{3}$ at $56.1 \mathrm{ppm}$ and the $\underline{\mathrm{CH}}_{3}$ at $20.9 \mathrm{ppm}$. IR spectrum of $5 \mathbf{a}$ showed the $\mathrm{N}-\mathrm{H}$ and $\mathrm{C}=\mathrm{O}$ stretching vibrations at 3258 and $1768 \mathrm{~cm}^{-1}$, respectively. The bands at 1336 and $1161 \mathrm{~cm}^{-1}$ represent sulfur-oxygen stretching frequencies in sulfone group $\left(\mathrm{SO}_{2}\right)$.

\section{Biological assays}

The inhibitory ability of the synthesized compounds (5a-5h) against some activities of the venoms of $B$. jararaca and $B$. jararacussu was investigated. The tested activities, coagulant, proteolytic, hemolytic,

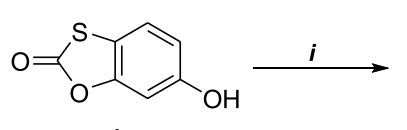

1<smiles>CC=C(C)C</smiles><smiles>COc1cc2oc(=O)sc2cc1[N+](=O)[O-]</smiles>

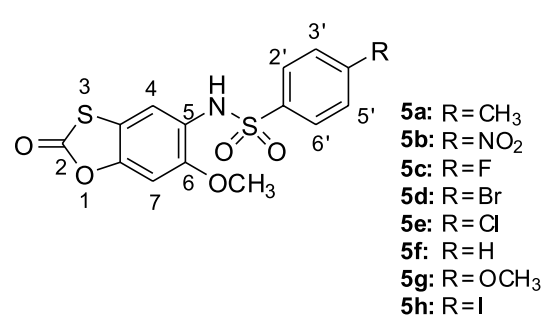

Scheme 1. Synthetic route used for preparing 5a-5h. $i$ : $\mathrm{HNO}_{3} 65 \%, \mathrm{CH}_{2} \mathrm{Cl}_{2}$, r.t., 2 h; ii: $\mathrm{CH}_{3} \mathrm{I}, \mathrm{K}_{2} \mathrm{CO}_{3}$, DMF, r.t., 24 h; $i i i: \mathrm{H}_{2}, 10 \% \mathrm{Pd} / \mathrm{C}, \mathrm{EtOH}, 20$ bar, $50{ }^{\circ} \mathrm{C}, 6-8 \mathrm{~h} ; i v$ : $\mathrm{p}-\mathrm{ArSO}_{2} \mathrm{Cl}$, pyridine, DMAP (1 equiv.), reflux, $8 \mathrm{~h}$. 
Table 1. Different methodologies tested to obtain the sulfonamide derivatives $\mathbf{5 a - 5 h}$

\begin{tabular}{|c|c|c|c|c|c|c|}
\hline entry & Solvent & Base & Catalyst & Temperature & $\mathrm{R}$ & Yield / \% \\
\hline 1 & acetonitrile & $\mathrm{K}_{2} \mathrm{CO}_{3}$ & - & r.t. & F & - \\
\hline 2 & acetonitrile & $\mathrm{K}_{2} \mathrm{CO}_{3}$ & DMAP (cat) & reflux & $\mathrm{F}$ & - \\
\hline 3 & THF & $\mathrm{K}_{2} \mathrm{CO}_{3}$ & - & r.t. & $\mathrm{F}$ & - \\
\hline 4 & THF & $\mathrm{K}_{2} \mathrm{CO}_{3}$ & DMAP (cat) & reflux & $\mathrm{F}$ & - \\
\hline 5 & acetone $/ \mathrm{H}_{2} \mathrm{O}$ & $\mathrm{K}_{2} \mathrm{CO}_{3}$ & - & r.t. & $\mathrm{CH}_{3}$ & - \\
\hline 6 & $\mathrm{AcOEt}$ & $\mathrm{Et}_{3} \mathrm{~N}$ & DMF (cat) & r.t. & $\mathrm{F}$ & - \\
\hline 7 & THF & $\mathrm{Et}_{3} \mathrm{~N}$ & DMAP (cat) & reflux & $\mathrm{CH}_{3}$ & - \\
\hline 8 & pyridine & pyridine & - & r.t. & $\mathrm{CH}_{3}$ & - \\
\hline 9 & pyridine & pyridine & DMAP (cat) & reflux & $\mathrm{CH}_{3}$ & - \\
\hline 10 & pyridine & DMAP (1 equ & & reflux & $\mathrm{CH}_{3}$ & 45 \\
\hline
\end{tabular}

THF: tetrahydrofuran; DMF: $N, N$-dimethylformamide; DMAP: 4-(dimethylamino)pyridine; cat: catalyst; r.t.: room temperature.

DMAP as base

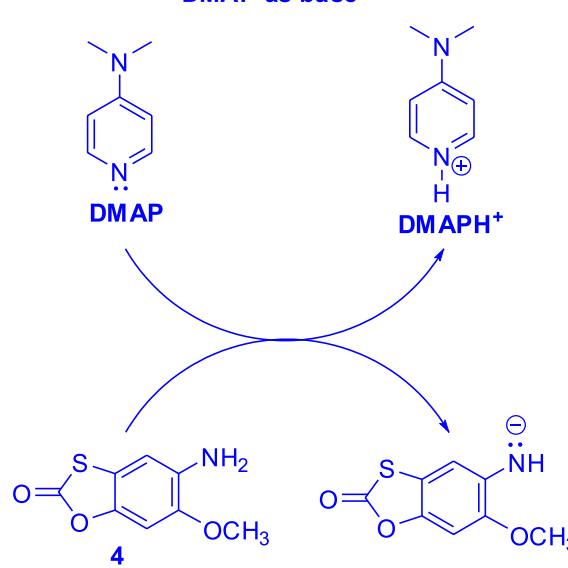

DMAP as nucleophilic catalyst<smiles>[R]c1ccc(S(=O)(=O)Cl)cc1</smiles><smiles>[CH]1C=CCC1</smiles>

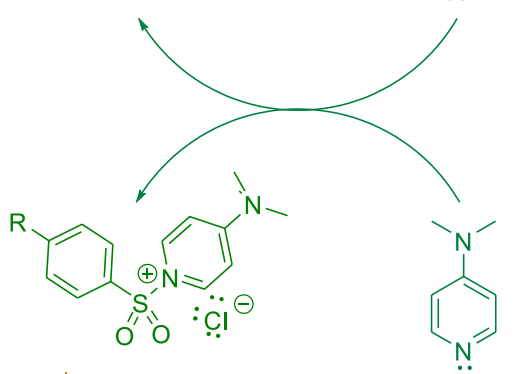

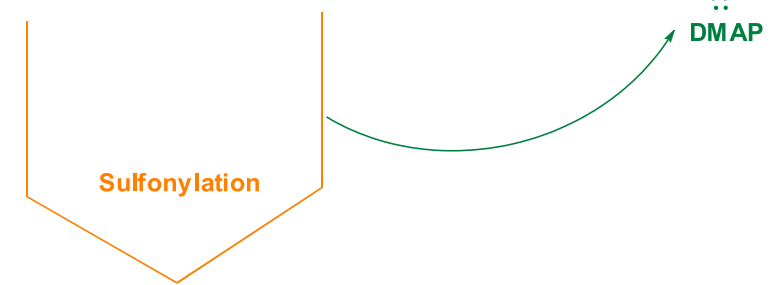

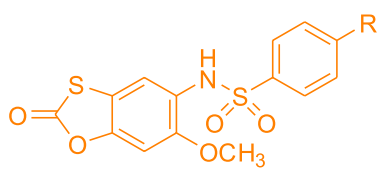

$5 a-5 h$

Figure 1. The role of DMAP as a base and nucleophilic catalyst in the synthesis of compounds $\mathbf{5 a - 5 h}$.

hemorrhagic, edematogenic, and lethality are responsible for the most important symptoms after snakebites, and cause into victims many toxic effects, leading to morbidities, amputation or deaths. Thus, it is essential to evaluate such activities of venoms to develop a candidate molecule as antivenom. It is worth mentioning that a similar ratio between $B$. jararaca or $B$. jararacussu venom and the compounds was used for most of all the in vitro and in vitro assays, that it was of 1:10 venom:compound $(\mathrm{m} / \mathrm{m})$. This strategy was employed to compare better the efficacy of neutralization of all compounds in each assay in this article as well as previous results of our group. ${ }^{19,20}$ 


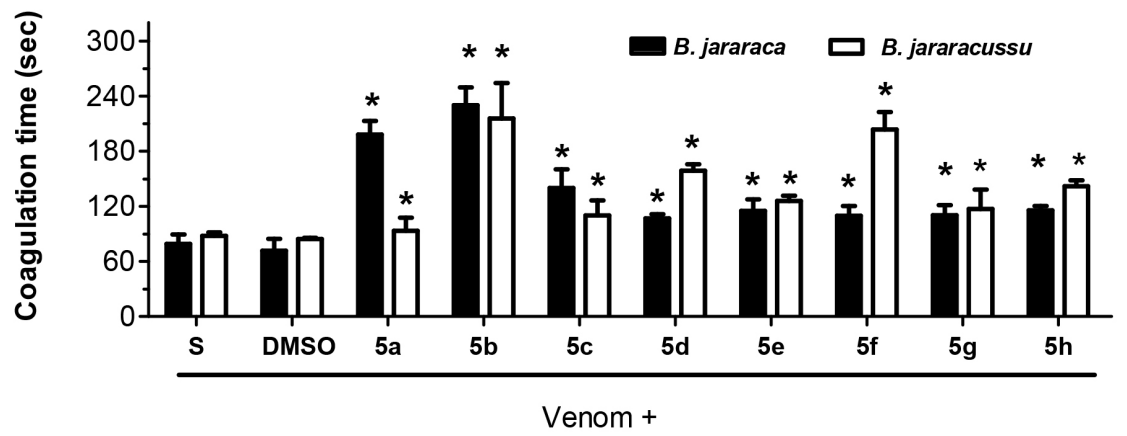

Figure 2. Effect of compounds on coagulation of the venoms of B. jararaca and B. jararacussu. Data are expressed as means \pm SD of three individual experiments $(\mathrm{n}=9) . * p<0.05$ when compared with control.

\section{Effect of compounds on in vitro activities of $B$. jararaca and B. jararacussu venoms}

\section{Anticoagulant activity}

Snake venoms are composed of many enzymes, which are responsible for toxic effects observed in victims. The snake venom serine proteases (SVSPs) and snake venom metalloproteases (SVMPs) enzymes are the most important and majority group of enzymes. They act on a variety of tissues and systems. SVSPs alter blood coagulation system, and most of them have thrombin-like activity, leading to the formation of fibrin, and thus, promoting the formation of thrombus. On the other hand, SVSPs may induce hemorrhage of victims because of the high consumption of fibrinogen, impairing blood to clot. In contrast, the SVMPs induce hemorrhage and coagulation of blood. Snakebites caused by the species of Bothrops genus provoke tissue necrosis and intravascular thrombin formation, resulting in coagulopathies and hemorrhage. However, B. jararaca venom is more hemorrhagic than B. jararacussu venom, due to presence of the SVMPs jararhagin ${ }^{28}$ and bothropasin, ${ }^{29}$ previously isolated from B. jararaca venom. On the other hand, B. jararacussu venom is more myotoxic due to the action of two myotoxins with phospholipase $\mathrm{A}_{2}\left(\mathrm{PLA}_{2}\right)$ structure, bothropstoxin I (Bthtx-I, without catalytic activity) and bothropstoxin-II (Bthtx-II, with catalytic activity). ${ }^{30,31}$ Thus, a molecule able to impair snake venom-induced coagulation, proteolysis or hemorrhage is relevant.

B. jararaca $\left(35 \mu \mathrm{g} \mathrm{mL}^{-1}\right)$ or B. jararacussu $\left(50 \mu \mathrm{g} \mathrm{mL}^{-1}\right)$ venom incubated with saline $(\mathrm{S})$ or DMSO $(0.9 \% \mathrm{v} / \mathrm{v}$, final concentration) clotted plasma around $80 \mathrm{~s}$ (positive control). When each snake venom was mixed with compounds (5a-5h), at a venom:compound ratio of $1: 10(\mathrm{~m} / \mathrm{m})$, a delay on plasma coagulation was observed (Figure 2). However, the compound $\mathbf{5 b}$ inhibited more efficiently coagulation of both venoms, around 220 s (Figure 2). Therefore, compounds inhibited the coagulation of venoms. The compounds alone did not clot plasma.
B. jararaca $\left(35 \mu \mathrm{g} \mathrm{mL} \mathrm{L}^{-1}\right.$, black columns) or B. jararacussu (50 $\mu \mathrm{g} \mathrm{mL}^{-1}$, white columns) venom was incubated with saline (S), DMSO (0.8\% v/v, final concentration), or with compounds 5a-5h (at a 1:10 venom:compound ratio $\mathrm{m} / \mathrm{m}$ ). Then, an aliquot of the mixture was added to plasma, and coagulation time (s) was monitored, as described.

\section{Antiproteolytic activity}

B. jararaca and B. jararacussu venoms are rich sources of proteases, and each venom was able to hydrolyze the chromogenic substrate, azocasein. Then, $100 \mu \mathrm{g} \mathrm{mL}^{-1}$ of compounds (5a-5h) were incubated with each venom $\left(10 \mu \mathrm{g} \mathrm{mL} \mathrm{m}^{-1}\right)$, as described in Experimental section. As shown in Figure 3, compounds $5 \mathbf{b}$ (39\%) and 5h $(27 \%)$ were the most efficient to inhibit proteolytic activity of $B$. jararacussu and B. jararaca venom, respectively. On the other hand, the compounds $\mathbf{5 d - 5 g}$ did not inhibit proteolysis of venoms (Figure 3 ). None of the compounds solely had proteolytic activity.

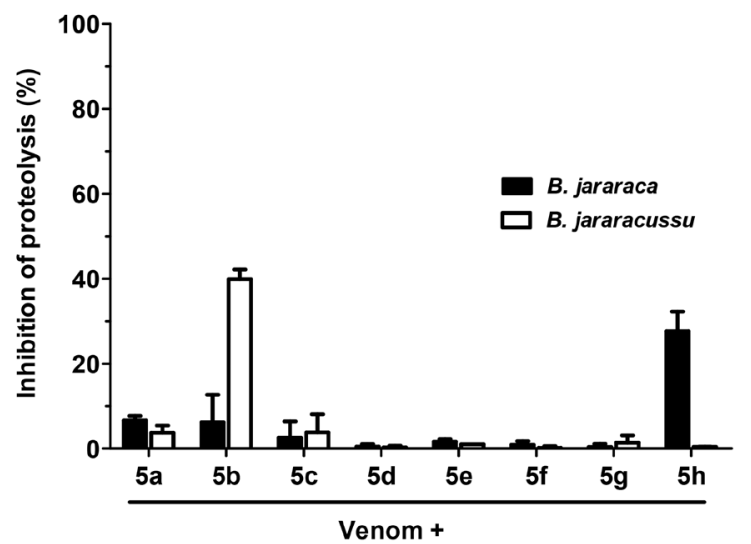

Figure 3. Inhibitory effect of compounds on proteolysis of $B$. jararaca and $B$. jararacussu venoms. The results express the means \pm SD of two individual experiments $(\mathrm{n}=6)$.

B. jararaca or B. jararacussu venom $\left(10 \mu \mathrm{g} \mathrm{mL}^{-1}\right)$ was incubated with $100 \mu \mathrm{g} \mathrm{mL}^{-1}$ of compounds $(\mathbf{5 a - 5 h})$ for $30 \mathrm{~min}$ at $25^{\circ} \mathrm{C}$, and then proteolytic activity was performed, as described. 


\section{Antihemolytic effect}

Hemolytic activity was not performed for the venom of $B$. jararacussu because it had low hemolytic activity. The concentration of $B$. jararaca venom $\left(24 \mu \mathrm{g} \mathrm{mL}^{-1}\right)$ that induced $100 \%$ of lysis of red blood cells was called minimum indirect hemolytic concentration (MIHC). This MIHC of venom ( $24 \mu \mathrm{g} \mathrm{mL}^{-1}$ ) was incubated with $240 \mu \mathrm{g} \mathrm{mL}^{-1}$ of compounds $(\mathbf{5} \mathbf{a}-\mathbf{5} \mathbf{h})$, and then hemolytic activity was performed, as described in Experimental section. As shown in Figure 4, the compounds $\mathbf{5 b}$ and $\mathbf{5 h}$ inhibited around $55 \%$, while the compounds 5d and 5e inhibited approximately 20\%. The compounds $\mathbf{5 a}, \mathbf{5 c}, \mathbf{5 f}$ and $\mathbf{5 g}$ did not inhibit hemolysis of B. jararaca venom. Hemolytic activity of snake venoms is due to the participation of another group of enzymes, phospholipase $\mathrm{A}_{2}\left(\mathrm{PLA}_{2}\right)$. Beyond hemolysis, $\mathrm{PLA}_{2}$ enzymes inhibit platelet aggregation, induce edema or myotoxicity, and, thus, participate in the development of tissue necrosis. None of the compounds solely induced hemolysis (data not shown).

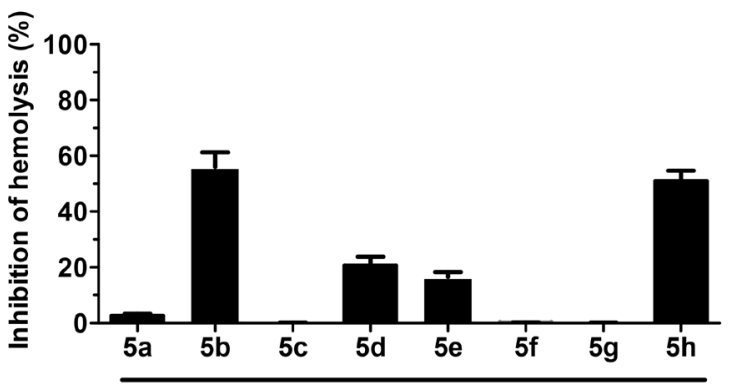

B. jararaca venom +

Figure 4. Inhibitory effect of compounds on hemolysis of $B$. jararaca venom. Data are expressed as means $\pm \mathrm{SD}$ of three individual experiments $(n=9)$.

$240 \mu \mathrm{g} \mathrm{mL}^{-1}$ of compounds (5a-5h) were incubated with B. jararaca venom $\left(24 \mu \mathrm{g} \mathrm{mL}^{-1}\right)$ for $30 \mathrm{~min}$ at $25^{\circ} \mathrm{C}$. Then, hemolytic test was performed, as described, and inhibition of hemolysis was determined.

It is noteworthy that the most active compound in inhibiting hemolysis of $B$. jararaca, and coagulation and proteolysis induced by both venoms, $(N-(6-$ methoxy-2-oxobenzo $[d]$ [1,3] oxathiol-5-yl)-4-nitrobenzenesulfonamide) (5b), bears the nitro group in its structure. The nitro group has a strong electron-withdrawing ability that creates localized or regional electron deficient sites within molecules, allowing interactions with biological nucleophiles present in living systems, such as proteins, amino acids, nucleic acids, and enzymes. The interaction may occur by a nucleophilic addition or displacement, by electron transfer involving oxidation and reduction, or simply by molecular complexation. ${ }^{32,33}$ This fact may suggest the importance of the nitro group for the biological activity. Among the halogenated compounds, the most active to prevent $B$. jararaca venom-induced hemolytic activity was the 4-iodo- $N$-(6-methoxy-2-oxobenzo[d] [1,3] oxathiol-5-yl)benzenesulfonamide (5h), which has an iodine atom on the benzene ring. Interestingly, a decrease in the inhibitory effect was observed with an increasing of halogen atom electronegativity, in the order, compound $\mathbf{5 h}$ (iodine), 5d (bromine), 5e (chlorine), 5c (fluorine). It is known that aromatic rings, such as benzene and its derivatives, act as ligands (Lewis base) in a variety of complexes, ${ }^{34}$ and the greater the electron density in the ring, greater the reactivity towards the metal cation, such as $\mathrm{Ca}^{2+}$, an ion that stimulate the activity of some $\mathrm{PLA}_{2}$ enzymes. It was observed that compound 5c did not inhibit hemolysis of $B$. jararaca venom. The presence of a fluorine atom, the most electronegative among halogens, may have contributed to the lack of activity. On the other hand, the iodine atom, the less electronegative, may have enabled a higher interaction between benzene ring and the $\mathrm{Ca}^{2+}$, through a cation- $\pi$ interaction, ${ }^{35}$ which corroborates with an inhibition around $55 \%$ for the compound $\mathbf{5 h}$.

Effect of compounds on in vivo activities of $B$. jararaca and $B$. jararacussu venoms

\section{Antihemorrhagic activity}

Injection intradermically (i.d.) of B. jararaca or B. jararacussu (24 $\mu \mathrm{g}$ per mice) venom produced a hemorrhage halo of around $20 \mathrm{~mm}$ that was considered as $100 \%$ of hemorrhagic activity. This dose of venom, which represents $2 \mathrm{MHD}$, was incubated for $30 \mathrm{~min}$ at $25^{\circ} \mathrm{C}$ with the compounds ( $240 \mu \mathrm{g}$ per mice). After incubation, the mixture was injected i.d. into mice, and hemorrhage was analyzed. As seen in Figure 5, all the compounds inhibited the hemorrhagic activity of venoms, but with different inhibitory percentages (from 6 to $62 \%$ ). Thus, the

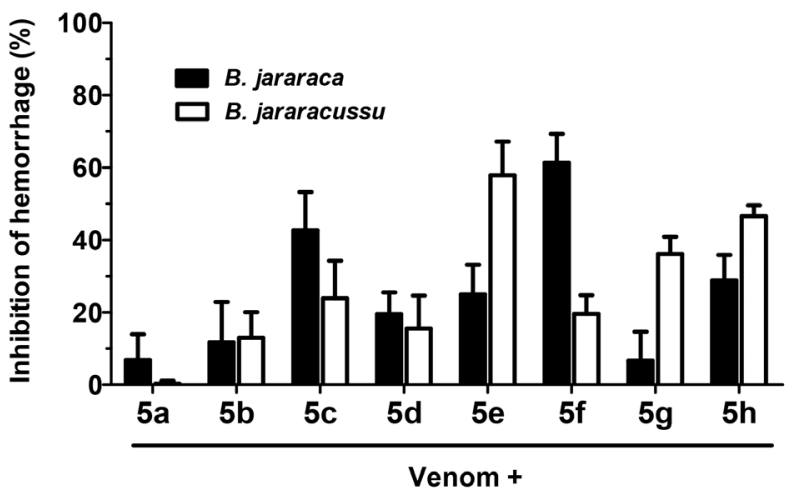

Figure 5. Inhibitory effect of compounds on B. jararaca and B. jararacussu venom-induced hemorrhage. Data are expressed as means \pm SD of two individual experiments $(\mathrm{n}=10)$. 
compounds interfered with SVMPs, maybe by chelating $\mathrm{Zn}^{2+}$, as they depend on this metal to display hemorrhagic activity. The compound $\mathbf{5 f}$ inhibited more efficiently $B$. jararaca venom-induced hemorrhage, probably due to its ability to bind to the main toxic enzymes of such venom, jararhagin ${ }^{28}$ or bothropasin. ${ }^{29}$ The compound 5a did not inhibit B. jararacussu-induced hemorrhage. Thus, one may speculate the inability of the compound $\mathbf{5 a}$ to bind to divalent cations (as $\mathrm{Zn}^{2+}$ or $\mathrm{Ca}^{2+}$ ), leading to an inefficacy to inhibit hemorrhagic (Figure 5) or hemolytic (Figure 4) activity of $B$. jararaca or $B$. jararacassu venom. None of the compounds or solvents induced hemorrhage.

B. jararaca (black columns) or B. jararacussu (white columns) venom (24 $\mu \mathrm{g}$ per mice) was mixed with $240 \mu \mathrm{g}$ per mice of compounds (5a-5h) for $30 \mathrm{~min}$ at $25^{\circ} \mathrm{C}$. Then, mixture was injected i.d. into mice, and hemorrhagic activity was analyzed, and expressed as inhibition of hemorrhage.

\section{Antiedematogenic activity}

Injection subcutaneously (s.c.) of B. jararaca or $B$. jararacussu venom ( $7 \mu \mathrm{g}$ per mice) into the paw of mice produced an increase of $40 \%$ on their paw volume, and such increase was considered as $100 \%$ of edematogenic activity. After, venom ( $7 \mu \mathrm{g}$ per mice) was incubated with the $20 \mu \mathrm{g}$ per mice of compounds (5a-5h) for $30 \mathrm{~min}$ at $25^{\circ} \mathrm{C}$. Then, mixture was injected s.c. into the paw of mice, and edema was analyzed. All compounds inhibited edema of B. jararaca and B. jararacussu venoms, from 35 to $72 \%$ (Figure 6). PLA $_{2}$ enzymes of venoms may contribute to edematogenic effect of venoms, as well. The PLA enzymes $_{2}$ need $\mathrm{Ca}^{2+}$ to display such activity, and the negatively charged structure of some compounds might bind to the active site of $\mathrm{PLA}_{2}$ enzymes and inhibit hemolytic activity or any other related toxic activity related to such enzymes, as edema. Neither the compounds nor solvents (saline or DMSO) induced edema.

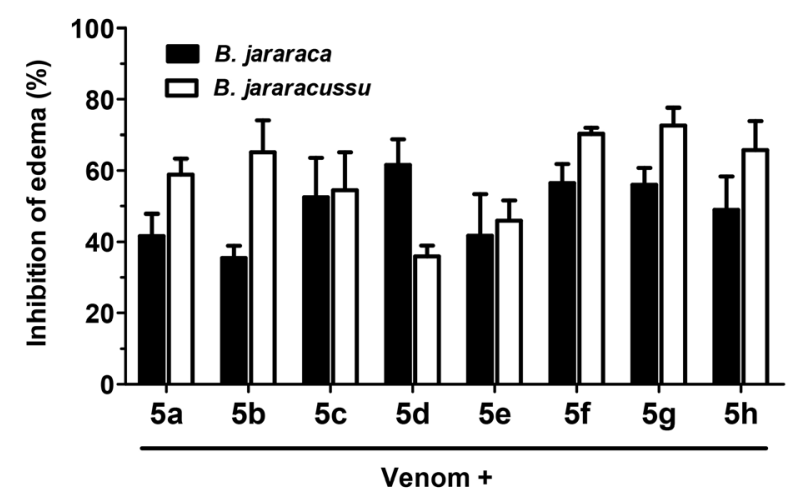

Figure 6. Inhibitory effect of compounds on edematogenic activity of $B$. jararaca and B. jararacussu venoms. Data are expressed as means \pm SD of two individual experiments $(n=10)$.
B. jararaca or B. jararacussu venom (7 $\mu \mathrm{g}$ per mice) was mixed with $20 \mu \mathrm{g}$ per mouse of compounds (5a-5h) for $30 \mathrm{~min}$ at $25^{\circ} \mathrm{C}$. Then, mixture was injected s.c. into mice and edematogenic activity was evaluated, as described, and inhibition of edema was determined.

\section{Antilethality activity}

A single intraperitoneal (i.p.) injection of $13 \mu \mathrm{g}$ per mice of B. jararaca or B. jararacussu venom incubated with saline or DMSO killed mice approximately in $65 \mathrm{~min}$. As seen in Table 2, $120 \mu \mathrm{g}$ per mice of the compounds (5a-5h) protected mice of the lethality of $B$. jararacussu venom. On the other hand, the compounds $\mathbf{5 a}, \mathbf{5 f}$ and $\mathbf{5 g}$ failed to protect mice of death caused by $B$. jararaca venom. Nevertheless, the other compounds did impair the death of mice induced by such venom. Injection of solely compounds did not cause death of mice, even at higher concentrations (up to $200 \mu \mathrm{g}$ per mice). The maximal time of observation of the survival of mice was $300 \mathrm{~min}$.

Table 2. Effect of compounds on lethality of $B$. jararaca and B. jararacussu venoms

\begin{tabular}{lcc}
\hline \multirow{2}{*}{ Group } & \multicolumn{2}{c}{ Survival time / min } \\
\cline { 2 - 3 } & B. jararaca & B. jararacussu \\
\hline Venom + saline & $65 \pm 17.4$ & $70 \pm 15.7$ \\
Venom + DMSO & $60 \pm 9.5$ & $63 \pm 17.9$ \\
Venom + compound 5a & $68 \pm 14.2$ & $300 \pm 19.1^{\mathrm{a}}$ \\
Venom + compound 5b & $130 \pm 8.1^{\mathrm{a}}$ & $300 \pm 20.2^{\mathrm{a}}$ \\
Venom + compound 5c & $160 \pm 18.1^{\mathrm{a}}$ & $240 \pm 12.3^{\mathrm{a}}$ \\
Venom + compound 5d & $140 \pm 10.4^{\mathrm{a}}$ & $200 \pm 14.2^{\mathrm{a}}$ \\
Venom + compound 5e & $160 \pm 11.4^{\mathrm{a}}$ & $300 \pm 11.2^{\mathrm{a}}$ \\
Venom + compound 5f & $70 \pm 17.4$ & $300 \pm 14.1^{\mathrm{a}}$ \\
Venom + compound 5g & $85 \pm 14.2$ & $200 \pm 10.2^{\mathrm{a}}$ \\
Venom + compound 5h & $300 \pm 22.1^{\mathrm{a}}$ & $300 \pm 0.1^{\mathrm{a}}$ \\
\hline Resuls are exprss
\end{tabular}

Results are expressed as means $\pm \mathrm{SD}(\mathrm{n}=5),{ }^{\mathrm{a}} p<0.05$ was compared with $B$. jararaca or $B$. jararacussu + saline or dimethyl sulfoxide (DMSO).

The compounds $\mathbf{5 a - 5 h}(120 \mu \mathrm{g}$ per mice $)$ were incubated for $30 \mathrm{~min}$ at $25^{\circ} \mathrm{C}$ with $B$. jararaca or B. jararacussu venom $(13 \mu \mathrm{g}$ per mice). Then, the mixture was injected i.p. into mice, and survival time was monitored. Control experiments were performed by incubating $B$. jararaca or B. jararacussu venom with saline or DMSO. The total time of observation of survival time of mice was $300 \mathrm{~min}$.

\section{Conclusions}

In summary, a series of eight novel 1,3-benzoxathiol-2one sulfonamide derivatives was successfully synthesized and characterized by IR, ${ }^{1} \mathrm{H}$ and ${ }^{13} \mathrm{C}$ NMR, and ESI-MS 
analysis. These compounds were able to inhibit some of the main toxic activities of the venom of B. jararaca or B. jararacussu, but with different potencies. Thus, being promising molecules to treat envenomation by these snakes as well as to aid the current antivenom serum therapy. However, it is quite difficult to postulate a mechanism of action of compounds based on their chemical structure, because snake venoms are a complex mixture of toxic proteins acting through unknown mechanisms of action.

\section{Supplementary Information}

Supplementary data are available free of charge at http://jbcs.sbq.org.br as PDF file.

\section{Acknowledgments}

The authors thank UFF, FAPERJ, CNPq, CAPES and Farmanguinhos/FIOCRUZ for their support. We wish to thank FAPERJ, CNPq and CAPES for research fellowships.

\section{Author Contributions}

Eliza de L. Chazin was responsible for the investigation of the synthesis and writing original draft; Leonardo B. Martins for the investigation of the synthesis; Marcus Vinícius N. de Souza and Claudia Regina B. Gomes for the writing review; Ana Cláudia R. da Silva for the investigation of the biological activity and writing original draft; Marcelly C. Branco for the investigation of the biological activity; Eladio F. Sanchez for the project administration; André L. Fuly for the project administration, writing original draft, writing review and editing of the biological activity; Thatyana R. A. Vasconcelos for the project administration, writing original draft, writing review and editing of the synthesis.

\section{References}

1. Chippaux, J.-P.; PLoS Neglected Trop. Dis. 2017, 11, e0005662.

2. World Health Organization (WHO); Snakebite Envenoming, available at https://www.who.int/news-room/fact-sheets/detail/ snakebite-envenoming, accessed in August, 2021.

3. Braud, S.; Bon, C.; Wisner, A.; Biochimie 2000, 82, 851.

4. Gutiérrez, J. M.; León, G.; Burnouf, T.; Biologicals 2011, 39, 129.

5. Gopi, K.; Anbasaru, K.; Renu, K.; Jayanthi, S.; Vishwanath, B. S.; Jayaraman, G.; Biochim. Biophys. Acta 2016, 1860, 1528.

6. Scheske, L.; Ruitenberg, J.; Bissumbhar, B.; Int. J. Health Policy Manage. 2015, 4, 447.

7. Mors, W. B.; Nascimento, M. C.; Pereira, B. M. R.; Pereira, N. A.; Phytochemistry 2000, 55, 627.

8. Katritzky, A. R.; Tetrahedron 1996, 52, xiii.
9. Balaban, A. T.; Oniciu, D. C.; Katritzky, A. R.; Chem. Rev. 2004, 104, 2777.

10. Patel, A. B.; Raval, R.; Importance of Heterocycles in Medicinal Chemistry; LAP Lambert Academic Publishing: New York, USA, 2015.

11. Jampilek, J.; Molecules 2019, 24, 3839.

12. Taylor, R. D.; MacCoss, M.; Lawson, A. D. G.; J. Med. Chem. 2014, 57, 5845.

13. Chazin, E. L.; Sanches, P. S.; Lindgren, E. B.; Vellasco Jr., W. T.; Pinto, L. C.; Burbano, R. M. R.; Yoneda, J. D.; Leal, K. Z.; Gomes, C. R. B.; Wardell, J. L.; Wardell, S. M. S. V.; Montenegro, R. C.; Vasconcelos, T. R. A.; Molecules 2015, 20, 1968.

14. Terra, L.; Chazin, E. L.; Sanches, P. S.; Saito, M.; de Souza, M. V. N.; Gomes, C. R. B.; Wardell, J. L.; Wardell, S. M. S. V.; Sathler, P. C.; Silva, G. C. C.; Lione, V. O.; Kalil, M.; Joffily, A.; Castro, H. C.; Vasconcelos, T. R. A.; Med. Chem. 2018, 14, 304.

15. Chazin, E. L.; Terra, L.; Moor, L. F. E.; Sanches, P. S.; Pinto, L. C.; Martins, T.; de Souza, M. V. N.; Gomes, C. R. B.; Montenegro, R. C.; Novais, J. S.; Carvalho, M. F.; Martins, F. J.; Figueiredo, A. M. S.; Joffily, A.; Castro, H. C.; Vasconcelos, T. R. A.; Rev. Virtual Quim. 2020, 12, 1586.

16. Vellasco Jr., W. T.; Gomes, C. R. B.; Vasconcelos, T. R. A.; Mini-Rev. Org. Chem. 2011, 8, 103.

17. Barrese III, A. A.; Genis, C.; Fisher, S. Z.; Orwenyo, J. N.; Kumara, M. T.; Dutta, S. K.; Phillips, E.; Kiddle, J. J.; Tu, C.; Silverman, D. N.; Govindasamy, L.; Agbandje-McKenna, M.; McKenna, R.; Tripp, B. C.; Biochemistry 2008, 47, 3174.

18. Mostert, S.; Petzer, A.; Petzer, J. P.; Bioorg. Med. Chem. Lett. 2016, 26, 1200.

19. Campos, V. R.; Abreu, P. A.; Castro, H. C.; Rodrigues, C. R.; Jordão, A. K.; Ferreira, V. F.; de Souza, M. C. B. V.; Santos, F. C.; Moura, L. A.; Domingos, T. S.; Carvalho, C.; Sanchez, E. F.; Fuly, A. L.; Cunha, A. C.; Bioorg. Med. Chem. 2009, 17, 7429.

20. Domingos, T. F. S.; Moura, L. A.; Carvalho, C.; Campos, V. R.; Jordão, A. K.; Cunha, A. C.; Ferreira, V. F.; de Souza, M. C. B. V.; Sanchez, E. F.; Fuly, A. L.; BioMed Res. Int. 2013, 2013, ID 294289.

21. Khan, F. A.; Mushtaq, S.; Naz, S.; Farooq, U.; Zaidi, A.; Bukhari, S. M.; Rauf, A.; Mubarak, M. S.; Curr. Org. Chem. 2018, 22, 818 .

22. Apaydin, S.; Török, M.; Bioorg. Med. Chem. Lett. 2019, 29 , 2042.

23. Garcia, E. S.; Guimarães, J. A.; Prado, J. L.; Arch. Biochem. Biophys. 1978, 188, 315.

24. Fuly, A. L.; de Miranda, A. L.; Zingali, R. B.; Guimarães, J. A.; Biochem. Pharmacol. 2002, 63, 1589.

25. Kondo, H. S.; Ikezawa, H.; Murata, R.; Jpn. J. Med. Sci. Biol. 1960, 13, 43. 
26. Yamakawa, M.; Nozaki, M.; Hokama, Z. In Animal, Plant and Microbial Toxins; Ohsaka, A.; Hayashi, K.; Sawai, Y., eds.; Plenum Press: New York, USA, 1976, p. 97.

27. Khashi, M.; Davoodnia, A.; Chamani, J.; Phosphorus, Sulfur Silicon Relat. Elem. 2014, 189, 839.

28. Paine, M. J.; Desmond, H. P.; Theakston, R. D.; Crampton, J. M.; J. Biol. Chem. 1992, 267, 22869.

29. Assakura, M. T.; Silva, C. A.; Mentele, R.; Camargo, A. C. M.; Serrano, S. M. T.; Toxicon 2003, 41, 217.

30. Gutiérrez, J. M.; Nunez, J.; Cintra, A. C. O.; Homsi-Brandeburgo, M. I.; Giglio, J. R.; Exp. Mol. Pathol. 1991, 55, 217.
31. Murakami, M. T.; Viçoti, M. M.; Abrego, J. R. B.; Lourenzoni, M. R.; Cintra, A. C. O.; Arruda, E. Z.; Tomaz, M. A.; Melo, P. A.; Arni, R. K.; Toxicon 2007, 49, 378.

32. Strauss, M. J.; Ind. Eng. Chem. Prod. Res. Dev. 1979, 18, 158.

33. Nepali, K.; Lee, H.-Y.; Liou, J.-P.; J. Med. Chem. 2019, 62, 2851.

34. Meyer, E. A.; Castellano, R. K.; Diederich, F.; Angew. Chem., Int. Ed. 2003, 42, 1210.

35. Dinadayalane, T. C.; Hassan, A.; Leszczynski, J.; Theor. Chem. Acc. 2012, 131, 1131.

Submitted: June 2, 2021

Published online: August 23, 2021 